\title{
Voting after violence: How combat experiences and post-war trauma affect veteran and voter party choices in Croatia's 2003 postwar elections
}

\begin{abstract}
:
This paper investigates the role of war experiences on voters and veterans' party choices in postwar elections. The literature has looked at the relation between military experience and electoral behavior, and at the political consequences of war-related psychological distress, yet has never integrated the two. This paper looks at the war experiences and specifically the development of war trauma on the likelihood of casting a vote for a nationalist party during a postwar election. Based on a 2003 survey of 1,000 Croatian voters, I find that veterans of Croatia's war of independence are more likely to vote for nationalist parties. However, voters who showed signs of trauma were less likely to vote for these parties. In addition, veterans suffering from psychological trauma after the war, they were far less likely to vote for nationalist parties.
\end{abstract}




\section{Introduction}

To what extent are the electoral choices of veterans and voters in postwar elections driven by the nature of their war experiences? Wars inflict death and destruction upon societies, disrupting them socially, economically, and politically. Yet the process of reintegration and democratic consolidation often requires individuals in these societies to let go of the past when making electoral choices, and to base their party preferences on current issues rather than their war experiences. The extent to which voters and veterans' vote choices are based on present-day policy preferences and interests can be seen as a sign of having moved beyond the war. Indeed, the extent to which voters' vote choices in general are based on today's needs is often considered a sign of a healthy democracy (Dahlberg, Linde, \& Holmberg, 2015; Diamond \& Morlino, 2005). As such, war experiences have the potential to disrupt the democratic process, preventing a society from moving forward. In addition, revisiting past conflicts can potentially lead to new tensions or conflicts between nations (He, 2007). Studying the extent to which war experiences continue to guide veterans' and voters' party preferences in postwar elections is thus an important step in answering questions related to peace-building and democratic consolidation.

While the literature has made great progress in understanding how war experiences affect electoral behavior, several important questions remain. First, the literature is split between two strands, one looking at the relation between military experience and electoral behavior, and another that looks at the political consequences of psychological distress resulting from exposure to war violence (Bonanno \& Jost, 2006; Canetti, Elad-Strenger, Lavi, Guy, \& Bar-Tal, 2017; Grossman, Manekin, \& Miodownik, 2015; Klingler \& Chatagnier, 2014). These two strands have developed largely independent from one another. While we therefore know that veterans are usually more rightwing or nationalist in their preferences than non-veterans are, we do not know whether psychological trauma resulting from combat experiences plays any role in that difference. Psychological distress is seldom included as a mediating or moderating factor in relation between veterans' military experience and their electoral behavior. To develop an encompassing model of how war experiences affect political behavior, these two literatures are in need of integration. 
Second, many of these studies look at the impact of war experiences at a time when the conflict is still ongoing. These studies often find that war experiences and trauma coincide with an increased tendency to vote for nationalist parties due to increased threat perceptions. However, in a genuine post-war context, with the absence of a threat, this relation is likely to be different. Studies on the political legacies of war often find that war experiences can have benign effects such as increased political participation (Blattman, 2009). While the literature has recently began examining voting in postwar settings (Glaurdić \& Vuković, 2016; Hadzic, Carlson, \& Tavits, 2017), most of these studies look at aggregated data. As a result, an analysis of the relation between war experiences and voting behavior at the micro level has yet to be done.

This paper seeks to contribute to filling these gaps in the literature. It does so by looking at the relation between combat experience, psychological trauma and the voting behavior of veterans and non-veterans in Croatia just after the parliamentary election of November 2003, eight years after Croatia's war of independence ended. Its aim is to integrate the literature on the psychological effects of war trauma among veterans with the literature on veterans' party preferences and voting behavior. To do so, we draw on the rich survey data of the South-East European Social Survey Project (SEESSP), which had the explicit goal of analyzing how war experiences affect postwar citizens (Simkus, 2007). Specifically, we study the extent to which voters and veterans' experiences in Croatia's war of independence (1991-1995) affected the likelihood of voting for a nationalist party in the Croatian parliamentary elections of November 2003. Nationalist parties are identified primarily by looking at the degree and the manner in which parties talk about nationalist issues such as national and traditional values and about national security in their 2003 election manifesto. Parties who heavily featured nationalist topics in their manifestos are considered nationalist parties.

In the wake of Yugoslavia's disintegration and Croatia's war of independence, nationalism surged in the country (Dyrstad, 2012). Nationalist parties stress the importance of national sovereignty, and the strengthening of the national identity (Fisher, 2006), and unsurprisingly, they dominated Croatian politics during the war. The question is, however, what happens after the war's end. Do voters let go of what happened in the war, or do their experiences during the war continue to influence their voting behavior? These are the questions this paper seeks to answer. 


\section{Combat experiences and party choice}

There are inevitable difficulties when trying to generalize findings from other countries and cases to Croatia's war of independence, yet something that all studies agree upon is that the impact of war is manifold. War can lead to material deprivation and to psychological distress due to either firsthand experiences or the loss of someone close. These experiences often lead to strong emotional responses, which in turn can affect how people vote. In the case of veterans, several studies have pointed to an increased tendency to vote for nationalist parties (Grossman et al., 2015; Klingler \& Chatagnier, 2014; Szayna, 2007; but also see Teigen, 2007), pointing to socialization in the military and combat experiences as explanatory mechanisms. These mechanisms could also apply to the case of Croatia.

Like many institutions, the military does more than teach soldiers how to fight. It also has a hidden curriculum (Jennings \& Markus, 1977). Military service inculcates soldiers with a sense of identification with the military, and servicemen are socialized to have negative attitudes towards possible threats (Bachman, Segal, Freedman-Doan, \& O’Malley, 2000; Grossman et al., 2015). Their identification with an institution that has as its very purpose the protection of the ingroup, combined with a hostility towards perceived outgroup threats, generates a natural affiliation with nationalism and nationalist parties. War veterans can thus be expected to show greater support for nationalist parties because these parties' identities resonate with the socialization soldiers have undergone during their time spent in the army. While these findings are born out of studies from other countries, it is highly likely that the Croatian military has a similar effect on its service members.

In addition, veterans' identification with the military and what it stands for - and by extension their increased tendency to vote for nationalist parties - can come about through a bottom-up dynamic. Identification can arise from the need to cope with potential risks to personal health and life that accompany military service, especially in an army engaged in warfare. Indeed, research has shown that an increased identification with one's social group strengthens an individual's ability to cope with stressful circumstances (Outten, Schmitt, Garcia, \& Branscombe, 2009). In this sense, military service and combat experience can to lead to the development of a nationalist party identification as a perceived justification of serving in the army or fighting in a war (Dekker, Malova, \& Hoogendoorn, 2003). This identification is 
arguably stronger if the particular war is a war of national independence, such as the Croatian Homeland War.

The above reasons search for the explanations of a possible preference for nationalist parties among veterans in the military service and combat experience itself. It is, however, possible that this preference came about prior to or after their service in the army. Military service is likely to attracts voters who are more nationalistic to begin with. Previous research has shown that aspiring enlistees are more militaristic and nationalist in their outlook (Bachman et al., 2000; Bachman, Sigelman, \& Diamond, 1987). As a result, the extent to which the difference in party preferences between veterans and non-veterans is the result of self-selection and socialization depends on how the army was recruited, and the extent to which this happened through volunteering and conscription. While there was conscription in the Croatia during the war, 30 per cent of the army was recruited through volunteering. ${ }^{1}$ As a result, the possibility that a preference for nationalist parties among veterans developed prior to military service cannot be excluded a priori and will have to be taken into account in the analyses of the data (see below).

Finally, after the war has ended, nationalist parties are more likely to favor generous benefits programs for veterans, as they did in Croatia as well (Glaurdić \& Vuković, 2016). This makes it often in the self-interest of veterans to vote for these parties. In sum, while the total relation between being a war veteran and the nationalist vote is probably mediated by several other variables such as prior attitudes and present-day policy positions, we contend that there is nevertheless a direct relation between combat experiences during the war and the likelihood of voting for a nationalist party. Moreover, we expect that these experiences of veterans continue to play a role in their electoral behavior after the conflict has ended. We therefore hypothesize that:

Hypothesis 1 (military service): War veterans are more likely to vote for a nationalist party in postwar elections than non-veterans.

How do postwar traumas affect one's willingness to vote for a nationalist party? Psychological trauma makes individuals feel diminished and vulnerable, seeing the world and other (out-group) individuals as potential threats (Staub, 2006). This distress can also occur among individuals who have not experienced violence firsthand. People's perceptions of events are influenced by their group memberships (Tajfel \& Turner, 1986). As a result, they may react emotionally to harm done to other group members, even though they themselves did not suffer directly, in what 
are often referred to as 'vicarious' or 'secondhand' victims (Wayment, 2004). Research has indeed shown that those individuals who lose someone in the course of a tragedy experience a great sense of powerlessness and distress (McBride \& Simms, 2001).

The obvious expectation would be that voters with a war-related psychological trauma would be more inclined to vote for nationalist parties. Studies support this notion, often finding that individuals who show signs of war-related emotional distress are more likely to vote for nationalist parties (Bonanno \& Jost, 2006; Canetti et al., 2017; Getmansky \& Zeitzoff, 2014; Kibris, 2011). The most convincing model of how trauma results in a nationalist vote argues that psychological distress or trauma leads to an increased tendency to see outgroups as threats to the in-group, resulting in conservative, militant ideologies designed to help individuals cope with highly threatening situations. These ideologies are collectively labelled the 'ethos of conflict', "shared societal beliefs that provide a particular dominant orientation to the society and give meaning to the societal life under conditions of intractable conflict" (Canetti et al., 2017, p. 90) and their presence favors nationalist parties.

However, almost all of these studies focus on cases of violence and war where the conflict is in one way or another still ongoing. In the case at hand, the war was over for eight years, and there was no indication that fighting might erupt again soon. Consequently, these findings are not transposable to the 2003 Croatian election. What happens then if the conflict is no longer ongoing? In those cases, with the threat being present, distress will increase the extent to which the outgroup is seen as threatening. With the threat no longer credibly present, it is possible that the increased threat perceptions do not occur, ending the development of an ethos of conflict.

Instead, in a postwar setting, it is more likely that individuals who have suffered trauma seek to avoid anything that reminds them of the war that caused it. Individuals who are reminded of the thing that caused the trauma show increased levels of psychological stress, even long after the event has occurred (Holman \& Silver, 1998). In short, reminding is reliving. Reliving hampers the ability of an individual to function in the present day, and forgetting the event is a way to cope with it (Levine, Lench, \& Safer, 2009). As a result, those who show signs of war-related distress arguably want to avoid anything that reminds them of that war.

Nationalist parties, however, are often very much associated with the past conflict, and frequently remind voters of the conflict even after its end, maintaining and reinforcing this 
association (Fisher, 2006), and Croatia is no exception in this regard. For traumatized individuals, these parties are thus associated with negative and stressful emotions, resulting in a negative attitude or aversion toward nationalist parties. Consequently, these voters might reject nationalist parties more often and be less likely to vote for them, as these parties remind them of what they endured during the war. This expectation is given credence by a study on the survivors of the siege of the Croatian town of Vukovar, which suffered greatly during Croatia's war of independence. It found that these survivors, though also voicing support for the punishment of the perpetrators, often just wanted to leave the war behind them (Biro et al., 2004). In sum, nationalism and nationalist parties remind voters of the war and, by extension, of war-related traumas. This negative association is expected to affect the party choices of voters with a war trauma. I therefore hypothesize:

\section{Hypothesis 2 (war trauma): Voters who suffered psychological trauma during the} war are less likely to vote for a nationalist party in postwar elections.

As discussed before, military service is likely to instill a nationalist worldview and a nationalist party preference among individuals with combat experience, and this is likely to persist after the war. However, just as with ordinary citizens, war trauma can have a profound effect on the worldview of veterans. Trauma often leads to disillusionment with society and to a certain degree of alienation from it (Brewin, Garnett, \& Andrews, 2011; Fontana \& Rosenheck, 1998). While few studies have examined the extent to which trauma affects the attitudes towards and identification with nationalist parties, research on traumatized veterans often reports disillusionment, alienation, and even resentment of the society for which they risked their lives. These attitudes, at the very least, are difficult to square with the support usually found among veterans in general for nationalist and rightwing parties. While support for these parties has not been included in any of these studies, they do seem to suggest that trauma can affect whether veterans vote for these parties, and that it affects this likelihood in a negative way.

We therefore posit that trauma negatively affects how veterans view nationalist parties and the likelihood that they will vote for them. Nationalism, in emphasizing the protection and sovereignty of the in-group, to a certain degree idealizes the struggle and wars to ensure this protection and achieve this sovereignty (Harari, 2005). The realities of war, however, contradict this image, and suffering a war trauma will arguably highlight this contradiction even more. 
Feaver and Gelpi (2005) showed that policy-makers that had served in the army where less likely to favor the use of force. A study on the recollection of the war among Croatian war veterans also indicated some support for this assertion (Ostojic, 2009). Veterans showed frustration at how the then-ruling nationalist party HDZ instrumentalized the war for the sake of domestic political propaganda. At the very least, this suggests that the relation between combat experience and the nationalist vote is more complex than is often assumed. We argue that the nature of these combat experiences, specifically the suffering of war trauma, moderates this relation. Support for nationalist parties among veterans is expected to be dependent on whether veterans show signs of psychological distress. We therefore hypothesize:

Hypothesis 3 (disillusionment): Veterans who are suffering from war-related psychological trauma are less likely to vote for a nationalist party in postwar elections than veterans who do not suffer from such trauma.

\section{Data and method}

To test these three hypotheses, this paper relies on a survey among Croatian voters conducted as part of the South-East European Social Survey Project (SEESSP). ${ }^{2}$ The project sought to study the impact of war on individuals and social groups during late 2003 and early 2004 in what is commonly referred to as the Western Balkans. The Croatian survey took place right after the Croatian parliamentary elections of November 2003, and therefore provides a good opportunity to study party preferences in postwar elections. Data were collected on the sample of 2280 eligible Croatian voters using face-to-face interviews. However, due to space limitations, questions related to war experiences were asked of only half of the sample. This brings the total usable sample of Croatian voters to $935 .^{3}$ Respondents were selected on the basis of a stratified multi-stage geographical cluster sample design, where the smallest sampling units were four to eight households (Ringdal \& Simkus, 2012; see Simkus, 2007).

Croatia's war of independence lasted from the summer of 1991 until to the summer of 1995 . It destroyed almost a third of Croatia's industrial infrastructure and claimed the lives of an estimated 20,000 citizens (Tanner, 1997). 
Due to the lack of a fully-fledged Croatian army, the Croatian police forces bore the brunt of the war's cost during its early stages. While the forces of the rebel Krajina Serbs, assisted by the Yugoslav Army, had some initial successes, the tide began to turn in Croatia's favor as the war continued. The war was effectively ended in the fall of 1995 with the Erdut Agreement, with Croatia being able to reclaim all of its previously occupied territory. In the eight years between the end of the conflict and the survey, there have been no serious violations of the agreement or indications that violence might erupt again. Therefore, Croatia in 2003 could be considered as a genuine postwar context, constituting an excellent case to study the impact of war in a postconflict society and in post-war elections.

The dependent variable, nationalist vote, indicates whether a voter voted for a nationalist party. The SEESSP survey included a question that asked each respondent which party he or she had voted for in, at the time of the survey, the last national election. This was a closed-ended question with 12 response options. To determine which one of these constituted a vote for a nationalist party, we rely on the Comparative Manifesto's Project (CMP) (Budge, 2001). This project has coded the 2003 programs of the majority of parties in Croatia, indicating the proportion of the manifesto that is devoted to a certain topic. In the first step, we summed the proportions of all the topics that relate to nationalism (see Table A1 in the appendix). However, this approach does not take into account the scope and breath of the manifesto. For instance, the Croatian Party of Rights (HSP) only had a one-page manifesto in 2003. Therefore, in a second step, we multiplied the score with the percentage of topic touched upon at least once in the manifesto. The result is a nationalism score for the political parties, shown in Figure 1. It is clear that there are primarily two nationalist parties, the Croatian Party of Rights (HSP) and the Croatian Democratic Party (HDZ). This result confirms how these parties have been discussed and treated in previous research (Fisher, 2006; Mudde, 2007; Ramet, 2006).

However, several parties were not included in the CMP, for which there are nevertheless strong indications that they can be considered nationalist parties. Between 2000 and 2003, HDZ began transforming into a conservative party, rather than just a nationalist party (Mudde, 2007). This led to several expulsions and party splits, which resulted in the formation of parties such as Croatian True Revival (HIP) and Croatian Bloc (HB). Finally, there was the Croatian Pure Party of Rights (HČSP), which was founded in response to internal conflicts within the HSP. 
Ideologically, however, it is very close to HSP, with a similar nationalist outlook (Irvine, 1997). For these reasons, these three parties are also considered nationalist parties. In sum, if a voter voted for the Croatian Party of Rights, the Croatian Pure Party of Rights, the Croatian Democratic Union, or Croatian Bloc \& Croatian True Revival ${ }^{4}$, then that voter is considered to have voted for a nationalist party in the 2003 elections. For voters who did not answer the question regarding vote choice, we used another question that asked voters which party they liked the most. Voters who did not answer both questions were excluded from the analyses 5 .

[Figure 1 about here]

The two main independent variables measure whether a respondent is a war veteran, and whether a respondent showed signs of war-related psychological trauma. These variables are all derived from various questions in the SEESSP survey. To capture whether a voter is a war veteran, we use a question asking each respondent whether he actively fought in Croatia's war of independence. The question does not directly ask whether the respondent has served in the Croatian military, but given the fact that police forces also fought in the war, the question used here arguably constitutes a better indicator.

To measure the second independent variable, war trauma, we rely on seven questions in the survey. These questions gauged whether respondents experienced intense feelings of fear or had shown symptoms such as a loss of memory on events related to the war, or emotional distress. An exploratory factor analysis indicated that these variables all relate to a single latent concept (factor loadings $>0.4$ ) and that they constitute a reliable scale (Cronbach's alpha $=0.84$ ). An overview of all seven items can be found in Table A2 the appendix.

However, there are inevitably differences between the questions with regards to the extent that they capture personal war trauma. To take these differences into account, war trauma is measured through factor scores, whereby the answers to the six questions are combined into one score, but where each answer is weighted according to the relation between the question and the latent concept of war trauma. A disadvantage of computing factor scores is their interpretability. To supplant this, personal war trauma is rescaled to assumed values between 0 and 7 so that ' 0 ' indicates an absence of trauma, and ' 7 ' signals strong signs of trauma. Another potential disadvantage is that factor scores can only be calculated for voters who answered all six questions. However, considering that the final sample still contains 935 voters, this (minor) 
decrease in sample size was found to be worth the increase in the quality of one of the variables of key interest.

One of the impetuses to look at how war experiences affect party preferences is that they potentially impede party choices from being made on the basis of present-day policy preferences. However, it is possible that war experiences affect contemporary policy preferences, which in turn affect party choices. As discussed above, war veterans might have held nationalist attitudes that steer them towards nationalist parties prior to the outbreak of the war. In addition, after the war, veterans might develop policy preferences that bring them closer to nationalist parties such as those related to social security benefits. In both cases, it are the policy preferences that ultimately guide party preferences and a nationalist vote.

The concern thus primarily focuses on the direct relation between war experiences and party preferences, not those mediated by policy preferences. To control for this, we include indicators for respondents' policy preferences, utilizing policy position questions included in the SEESSP survey. ${ }^{6}$ An exploratory factor analysis of those policy attitudes revealed three latent value preference dimensions. The first relates to preferences towards economic attitudes and redistribution (e.g. "Differences in income in this country are too large"). The second captures attitudes towards gender equality (e.g. "Most housework is naturally the job of the woman"), and the third relates to the rights of minorities living in Croatia (e.g. "Should minorities have the right to schools in their own language?). ${ }^{7}$ To measure each preference dimension, we calculate the mean values of the policy attitude questions in the survey. ${ }^{8}$ The measures for each dimension had an acceptable levels of reliability (Cronbach's alpha $>0.7$ ).

In addition, the war experiences of voters can correlate with their present-day social positions. For instance, research in Croatia shows that having fought in the war of independence is related to lower levels of education and income (Kecmanovic, 2013). These social positions can in turn affect the likelihood of voting for a nationalist party. We therefore control for several individual and contextual or county characteristics. On the individual level, all analyses account for a respondent's gender, age, years of education, unemployment status, and whether a voter belongs to an ethnic minority. At the county-level, we control for the level of unemployment, the ethnic homogeneity (percentage of ethnic Croats in the county's population), and the degree of 
urbanization (the percentage of the county's population living in urban areas). Table 1 gives an overview of the descriptives of all the variables.

As some variables are situated at a higher level, the county-level, multilevel modeling is used in order to avoid analyses being overpowered (Rabe-Hesketh \& Skrondal, 2008). Using regular logistic regression would result in the coefficients of the county-level variables being calculated on the basis of 935 observation (number of voters in the sample) instead of on the basis of 21 observations ${ }^{9}$, underestimating their standard errors. Therefore, we use multilevel logistic regression with a random intercept for the county-level.

[Table 1 about here]

\section{Results}

The purpose of this study is to analyze how war experiences affect the likelihood of voting for a nationalist party in postwar elections. From the descriptives in Table 1, we learn that overall about 37 percent of survey respondents voted for a nationalist party in the 2003 elections, which is only slightly lower than the $41 \%$ nationalist parties actually won. Before testing the three hypotheses, we look at the descriptives of party choice. Table 2 shows the support for the four nationalist vote options in the 2003 elections in the survey among both veteran and non-veteran respondents. We see that for the latter group nationalist parties account for 33 percent of the votes. In contrast, 57 percent of veterans vote for one of the four nationalist vote choices. This suggests an increased support for nationalist parties among war veterans.

\section{[Table 2 about here]}

The descriptives are in line with the prediction of the first hypothesis, which argues that veterans of the war of independence, likely due to the nationalist sentiments they develop during their time in the military or as a result of the risk to their own lives, are more likely to vote for a nationalist party. The second hypothesis, however, claims that voters who suffered a war-related psychological trauma are less likely to cast a nationalist vote. The fact that war features heavily in the rhetoric of nationalist parties serves as a constant reminder of what these traumatized voters endured, which is expected to generate an aversion towards nationalist parties. 
These two hypotheses are formally tested in Table 3. Model 1 contains only the war experiences and thus shows their total effect on the likelihood to vote for a nationalist party. Models 2 and 3 each introduce additional covariates aimed at controlling for the mediated effects of war experiences; making the test of the two hypotheses more stringent every time. Model 2 contains the policy preference measures, and model 3 brings in the socio-demographic information, both on the individual and on the county level. As a result, the final model shows the direct effects of war experiences on nationalist voting preferences. To make more sense of these relations and to give an idea of the effect sizes, we calculate the predicted probabilities of voting for a nationalist party at various levels of the independent variables. These predicted probabilities are shown in Figure 2.

All three models show that war experiences are related to voting for a nationalist party. Furthermore, this relation remains almost undiminished by the introduction of alternative explanations. However, it is clear that the direction of the relation between war experiences and voting behavior is not unidirectional. Being a war veteran increases the likelihood of voting for a nationalist party, from 32 percent among non-veterans to roughly 50 percent among veterans.

However, some caution is advised when interpreting these results as indicating that the war experiences of these veterans are behind the increased preference for nationalist parties. In the absence of a pre-war measurement of their party preferences, it is likely that part of the difference we find between veteran and non-veterans is due to fact that nationalist voters are more likely to join the army and not due to their time in the army or their war experiences. In other words, while I believe the results are strong enough to support hypothesis 1 , the analyses most likely overestimate the war-induced party preference differences between veterans and nonveterans.

Among voters who experienced psychological distress because of the war, I find the opposite. Those who show strong signs of trauma have a 26 percent chance of voting for a nationalist party, while the support for nationalist parties among those without any sign of trauma is about 53 percent. In sum, the impact of combat experience and war-related psychological trauma is real and substantial, supporting hypothesis 2 .

Finally, hypothesis 3 predicts that a war-related psychological trauma moderates the relation between being a veteran and the likelihood of voting for a nationalist party. War traumas are 
expected to result in disillusionment with the idealization of the struggle for independence by nationalist parties. As a result, veterans with a war trauma are expected to be less likely to vote for nationalist parties than veterans who show little or no signs war-related psychological distress. This hypothesis is tested in Model 4 in Table 3. The model points to a significant interaction effect between being a war veteran and trauma, in line with hypothesis 3 .

The predicted probabilities of this moderation effect are depicted in Figure 3. Among veterans without signs of war-related trauma, the likelihood of voting for a nationalist party is very high: more than 80 percent of non-traumatized war veterans vote for a nationalist party. The stronger the signs of trauma among veterans, however, the less likely a nationalist vote becomes. Among veterans who show very strong signs of PTSD and trauma, the support for nationalist parties drops to about 27 percent, statistically indistinguishable from the support among non-veterans. What this interaction shows is that it is not only military service or combat experience that matters for the voting behavior of veterans, but also what that service and those experiences entailed. If fighting in the war resulted in psychological trauma, veterans are more likely to turn away from nationalist parties.

If we look at the control variables, the results show that preferences towards more gender equality are related to a lower probability to vote for a nationalist party. Unsurprisingly, being against granting rights to minorities increases the chance of voting for a nationalist party. In addition, economic policy preferences do not play a role in explaining voters' party choices. Furthermore, additional years of education and being a member of a minority group make it less likely that a voter will vote for a nationalist party. A closer examination shows that it is primarily voters with a higher level of education (university degree or higher) that are less likely to vote for nationalist parties. Finally, the support for nationalist parties is lower in municipalities with a larger minority community. The probability to vote for a nationalist party in the least ethnically homogeneous county ( $72 \%$ Croats) is about $22 \%$, while it is $41 \%$ in the most ethnically homogeneous (98\% Croats). This finding is in line with the predictions of contact theory, which states that contact between groups help improve relations between those groups (Pettigrew and Tropp 2006).

[Table 3 about here]

[Figure 2 about here] 
[Figure 3 about here]

\section{Conclusion}

This paper examined the extent to which voters and veterans vote for nationalist parties in postwar elections, and how the nature of their war experiences affects this. While scholarly attention has been given to the impact of trauma and the exposure to violence on the vote choice of ordinary citizens, and to the link between combat experience and party identification, these two strands in the literature have developed in parallel. This study sought to integrate them and provide insights into how the nature of veterans' combat experiences affect their party choices. In addition, this paper contributes to a growing literature on the nature of electoral behavior in postwar settings. In addition, most studies examine the electoral legacies of war experiences in contexts in which the conflict is still ongoing. The purpose of this paper was to explore these gaps in the literature, and in doing so, contribute to the debate on the legacies of war and democratic consolidation.

Based on a representative survey among Croatian voters taken eight years after the end of the Croatian war of independence, we found that, in line with previous studies, war veterans are more likely to vote for a nationalist party. A war-related war trauma, however, had the opposite effect: voters who had shown clear signs of trauma were less likely to vote for a nationalist party. In addition, we found that the link between combat experience and voting for a nationalist party depended on what veterans experienced during the war. When veterans suffered from psychological trauma after the war, they were far less likely to vote for these parties.

Our findings also have normative implications. On the one hand, our results give reason to be hopeful about postwar societies, as they show that war experiences do not have to lead to an ethos of conflict, and can even lead to an aversion towards parties embracing this ethos. On the other hand, the impetus to investigate these issues rises from a concern that postwar societies are stuck in their (war) past, with voters making decisions and choices based on wartime experiences instead of present-day conditions and preferences. In this sense, any relevance of war experiences in explaining contemporary voting behavior is normatively undesirable. This paper shows that voters' decisions during elections are to an important degree motivated by past war. 
Overall, the results indicate that the impact of war can still be felt in postwar politics almost a decade after the conflict's end.

Although we believe the evidence to be novel and the findings compelling, the study clearly has limitations. The first is that the relations between war experiences and party preferences are studied at one point in time, specifically eight years after the end of a conflict. Could it be that the strength of the results reported in this paper decreases as the time between the present and the end of the war increases? Possibly, but studies do not seem to suggest this to be the case. Studies on the electoral consequences of war report an impact of war on electoral outcomes in postwar societies at various moments after the conflict's resolution (Glaurdić \& Vuković, 2016).

The second major shortcoming is the focus on a single country. It is possible that the specific nature of the Croatian war of independence affected the results. It could for instance be that the impact of combat experience on voting for nationalist parties is different when the war is fought overseas instead of on the country's own territory. In addition, Croatia came out of the war as a victor, achieving independence and being able to keep all territory claimed at the outbreak of the war. This could have affected the degree to which veterans are drawn to nationalist parties.

The exact results are obviously not simply generalizable to other contexts. Nonetheless, the approach and explanations suggested in this paper offer a useful way to start thinking more systematically about war experiences and their role in postwar electoral behavior, as well as the consequences for democratic consolidation this may entail. The relation between war experiences and electoral behavior is more complex than previously presumed, and this article presents an approach that can contribute to our understanding of the electoral legacies of war, support for nationalist parties in postwar elections, and democratic consolidation in general. 
Table 1: Descriptives of the variables

\begin{tabular}{|c|c|c|c|c|}
\hline & Mean & S.D. & Min. & Max. \\
\hline $\begin{array}{l}\text { Nationalist vote } \\
\quad(1=\text { yes; } 0=\text { no; dependent variable })\end{array}$ & 0.37 & 0.48 & 0 & 1 \\
\hline War veteran $(1=$ yes; $0=$ no $)$ & 0.14 & 0.35 & 0 & 1 \\
\hline $\begin{array}{l}\text { War trauma } \\
\qquad(0=\text { no signs of trauma; } 7=\text { strong signs of trauma })\end{array}$ & 2.29 & 1.51 & 0 & 7 \\
\hline $\begin{array}{l}\text { Economic policy preferences } \\
\text { (1=favoring government involvement; } \\
5=\text { disfavoring government involvement) }\end{array}$ & 1.79 & 0.59 & 1 & 4.4 \\
\hline $\begin{array}{l}\text { Gender equality preferences } \\
\text { ( } 1=\text { anti equality; } 5=\text { pro equality) }\end{array}$ & 2.96 & 0.82 & 1 & 5 \\
\hline $\begin{array}{l}\text { Preferences towards minority rights } \\
\qquad(1=\text { pro minority rights; } 2=\text { anti minority rights })\end{array}$ & 1.52 & 0.26 & 1 & 2 \\
\hline Gender ( $1=$ male; $2=$ female $)$ & 1.56 & 0.5 & 1 & 2 \\
\hline Age (years) & 46.77 & 16.93 & 20 & 91 \\
\hline Years of education & 11.4 & 3.94 & 0 & 23 \\
\hline$(1=$ yes; $0=$ no $)$ & 0.13 & 0.33 & 0 & 1 \\
\hline Ethnic minority $(1=$ yes; $0=$ no $)$ & 0.08 & 0.27 & 0 & 1 \\
\hline County's unemployment rate (\%) & $17.35 \%$ & $6.47 \%$ & $6.99 \%$ & $29.55 \%$ \\
\hline County's \% of ethnic Croats & $89.87 \%$ & $6.65 \%$ & $71.88 \%$ & $98.44 \%$ \\
\hline County's degree of urbanization $(\%)$ & $60.85 \%$ & $22.03 \%$ & $13.90 \%$ & $95.20 \%$ \\
\hline
\end{tabular}

Note: $n=935$

Table 2: Nationalist party support among veterans and non-veterans

\begin{tabular}{|c|c|c|c|}
\hline & $\begin{array}{l}\text { Overall } \\
\text { support }\end{array}$ & $\begin{array}{c}\text { Support among } \\
\text { non-veterans }\end{array}$ & $\begin{array}{c}\text { Support among } \\
\text { veterans }\end{array}$ \\
\hline Croatian Democratic Union (HDZ) & $29.30 \%$ & $27.82 \%$ & $38.47 \%$ \\
\hline Croatian party of rights (HSP) & $5.99 \%$ & $4.47 \%$ & $15.38 \%$ \\
\hline $\begin{array}{l}\text { Croatian Pure Party of Rights ( HČSP) \& } \\
\text { Croatian Christian Democratic Union (HKDU) }\end{array}$ & $0.32 \%$ & $0.13 \%$ & $1.53 \%$ \\
\hline $\begin{array}{l}\text { Croatian Bloc (HB) \& Croatian True Revival } \\
\text { (HIP) }\end{array}$ & $0.96 \%$ & $0.87 \%$ & $1.53 \%$ \\
\hline Non-nationalist parties & $63.43 \%$ & $66.71 \%$ & $43.08 \%$ \\
\hline Total & $100 \%(935)$ & $100 \%(805)$ & $100 \%(130)$ \\
\hline
\end{tabular}




\begin{tabular}{|c|c|c|c|c|c|c|c|c|c|c|c|c|}
\hline & \multicolumn{3}{|c|}{ Model 1} & \multicolumn{3}{|c|}{ Model 2} & \multicolumn{3}{|c|}{ Model 3} & \multicolumn{3}{|c|}{ Model 4} \\
\hline & B & S.E. & Sig. & $\mathrm{B}$ & S.E. & Sig. & B & S.E. & Sig. & B & S.E. & Sig. \\
\hline War veteran & 0.85 & $(0.20)$ & $* * *$ & 0.86 & $(0.21)$ & $* * *$ & 0.79 & $(0.24)$ & $* * *$ & 1.94 & $(0.61)$ & $* *$ \\
\hline Personal war trauma & -0.20 & $(0.08)$ & $* *$ & -0.19 & $(0.08)$ & $*$ & -0.26 & $(0.08)$ & $* *$ & -0.16 & $(0.10)$ & $\dagger$ \\
\hline Economic policy preferences & & & & -0.01 & $(0.13)$ & & 0.01 & $(0.13)$ & & 0.00 & $(0.13)$ & \\
\hline Gender equality preferences & & & & -0.49 & $(0.10)$ & $* * *$ & -0.53 & $(0.11)$ & $* * *$ & -0.52 & $(0.11)$ & $* * *$ \\
\hline Minority rights preferences & & & & 1.00 & $(0.28)$ & $* * *$ & 0.74 & $(0.29)$ & $*$ & 0.72 & $(0.29)$ & $*$ \\
\hline Gender & & & & & & & 0.02 & $(0.17)$ & & 0.02 & $(0.17)$ & \\
\hline Age & & & & & & & -0.02 & $(0.01)$ & $* * *$ & -0.02 & $(0.01)$ & $* * *$ \\
\hline Years of education & & & & & & & -0.08 & $(0.02)$ & $* * *$ & -0.07 & $(0.02)$ & $* *$ \\
\hline Unemployed & & & & & & & 0.03 & $(0.22)$ & & 0.05 & $(0.22)$ & \\
\hline Ethnic minority & & & & & & & -1.29 & $(0.36)$ & $* * *$ & -1.33 & $(0.37)$ & $* * *$ \\
\hline County's unemployment rate & & & & & & & 2.68 & $(1.47)$ & $\dagger$ & 2.83 & $(1.52)$ & $\dagger$ \\
\hline County's \% of ethnic Croats & & & & & & & 0.03 & $(0.01)$ & $*$ & 0.03 & $(0.01)$ & $*$ \\
\hline County's degree of urbanization & & & & & & & 0.00 & $(0.00)$ & & 0.01 & $(0.00)$ & \\
\hline \multirow{3}{*}{$\begin{array}{l}\text { Interaction term: } \\
\text { War veteran*Personal war trauma } \\
\text { Constant }\end{array}$} & \multirow{3}{*}{\multicolumn{3}{|c|}{$-0.08 \quad(0.26)$}} & \multirow{3}{*}{\multicolumn{3}{|c|}{$-0.26 \quad(0.61)$}} & \multirow{3}{*}{\multicolumn{3}{|c|}{$-1.54 \quad(1.60)$}} & & & \\
\hline & & & & & & & & & & -0.44 & $(0.21)$ & $*$ \\
\hline & & & & & & & & & & -1.91 & $(1.66)$ & \\
\hline $\mathrm{N}$ (voters / counties) & \multirow{2}{*}{\multicolumn{3}{|c|}{$\begin{array}{c}935 / 21 \\
0.20(0.11)\end{array}$}} & \multirow{2}{*}{\multicolumn{3}{|c|}{$\begin{array}{c}935 \text { / } 21 \\
0.09(0.07)\end{array}$}} & \multirow{2}{*}{\multicolumn{3}{|c|}{$\begin{array}{c}935 / 21 \\
0.02(0.06)\end{array}$}} & \multirow{2}{*}{\multicolumn{3}{|c|}{$\begin{array}{c}935 \text { / } 21 \\
0.030(.06)\end{array}$}} \\
\hline Variance component (S.E.) & & & & & & & & & & & & \\
\hline
\end{tabular}

Note: Multilevel logistic regression; $\dagger=p \leq 0.10 ; *=p \leq 0.05 ; * *=p \leq 0.01 ; * * *=p \leq 0.001$ 
Figure 1: Nationalism in Croatia's party programs in 2003

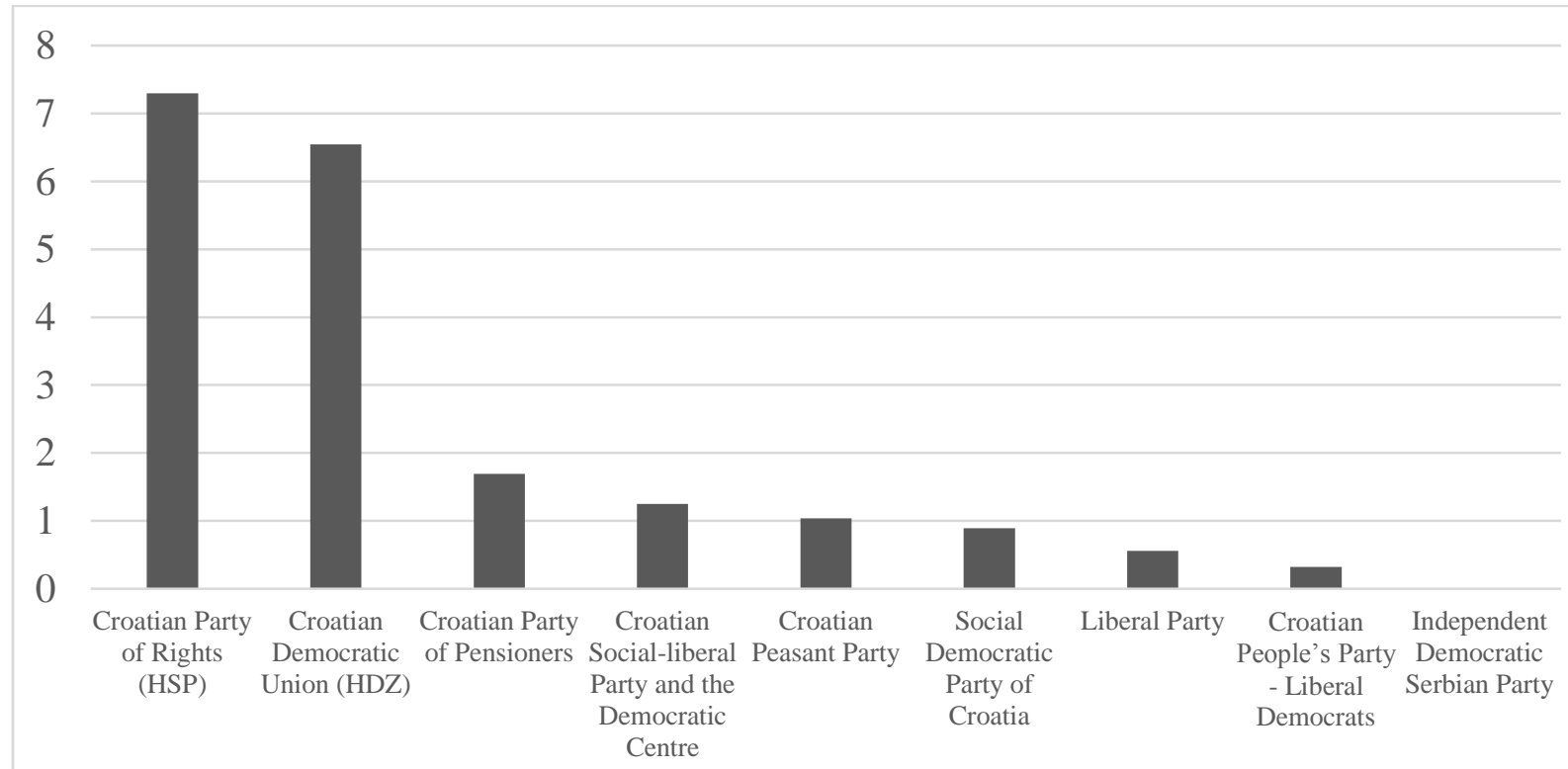

- Nationalism score

Figure 2: The direct relation between war veteran, war trauma, and a nationalist vote

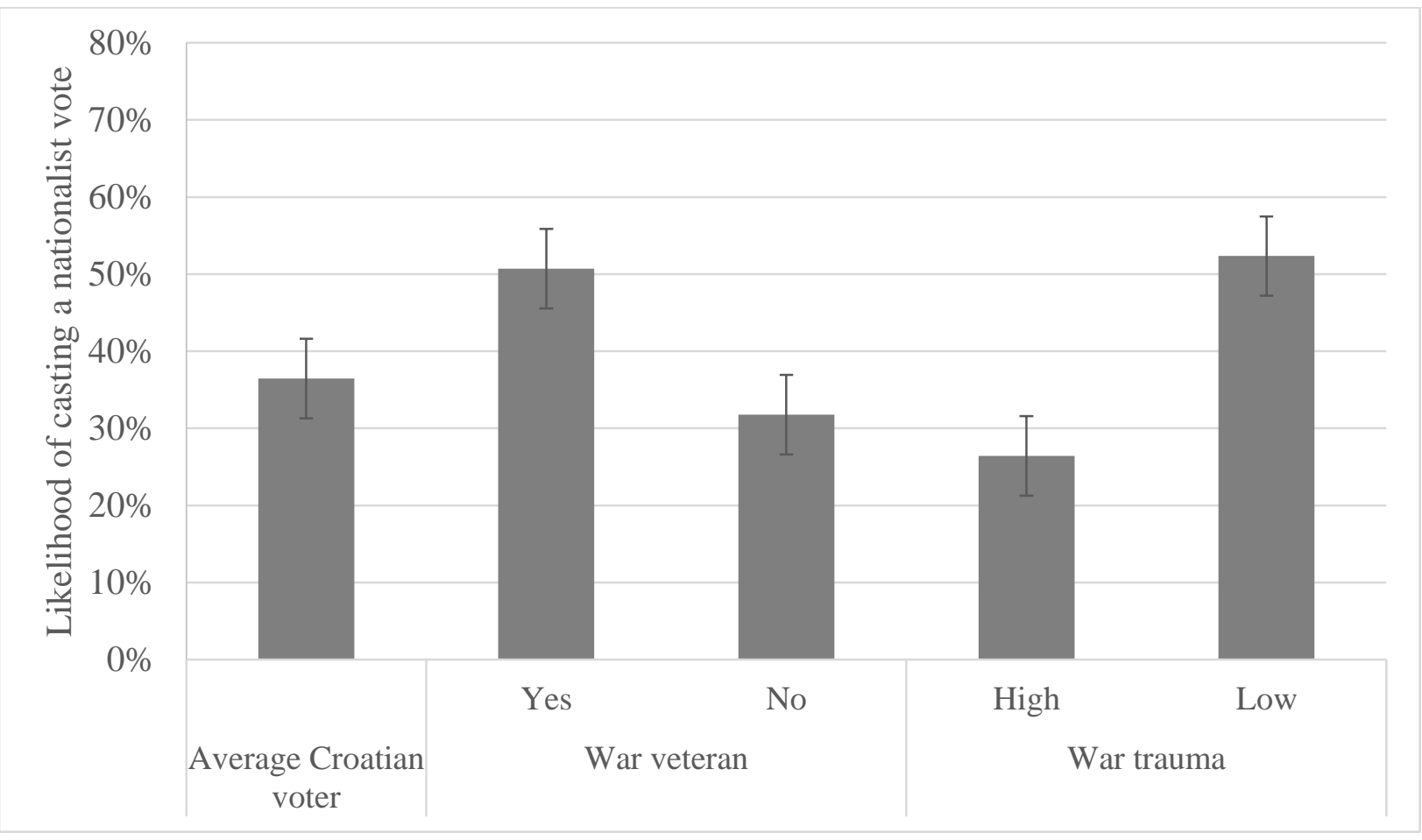


Figure 3: The interaction between being a war veteran, war trauma, and the nationalist vote

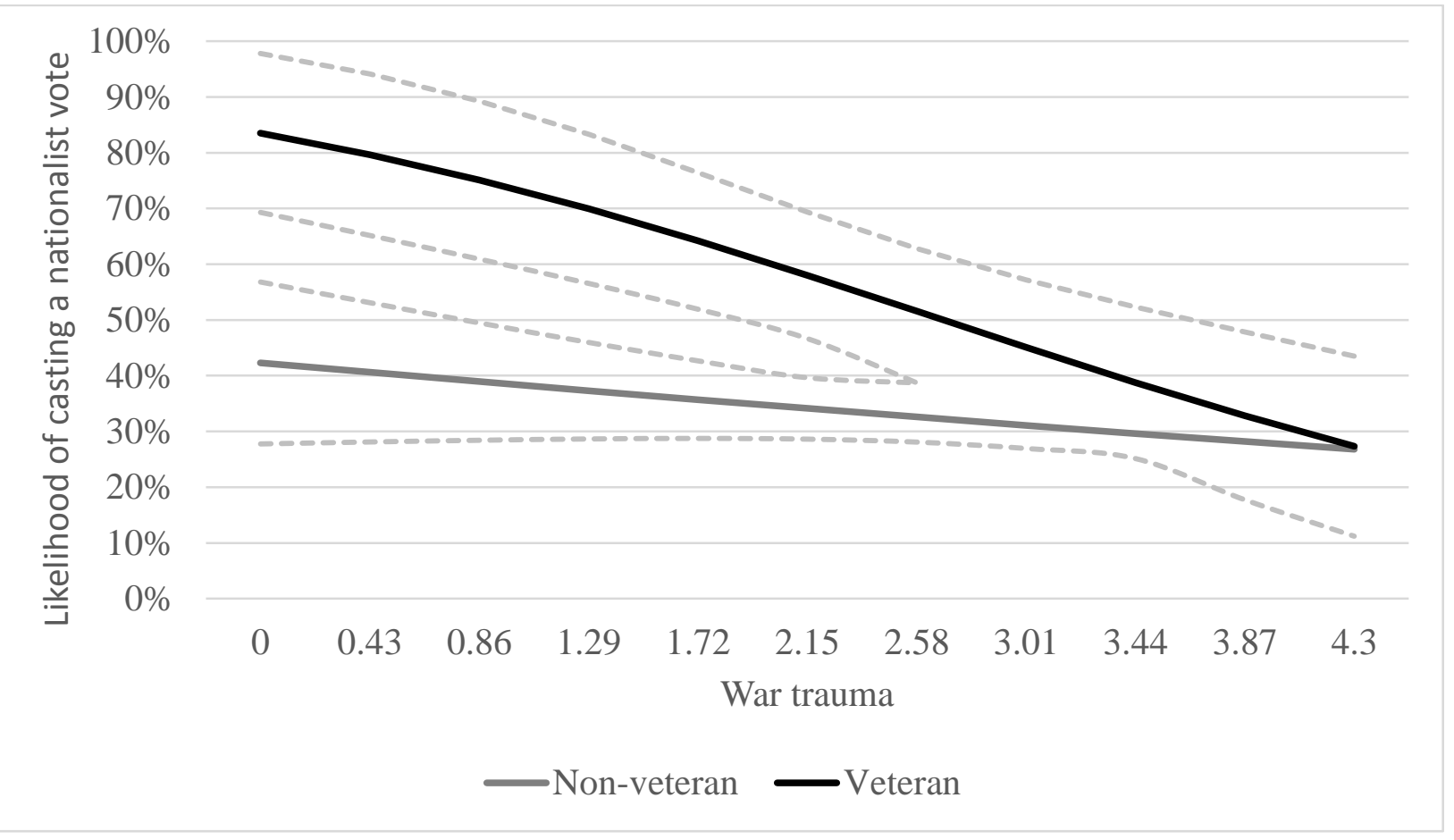




\section{Cited literature}

Bachman, J. G., Segal, D. R., Freedman-Doan, P., \& O’Malley, P. M. (2000). Who chooses military service? Correlates of propensity and enlistment in the U.S. Armed Forces. Military Psychology, 12(1), 1-30. https://doi.org/10.1207/S15327876MP1201_1

Bachman, J. G., Sigelman, L., \& Diamond, G. (1987). Self-Selection, Socialization, And Distinctive Military Values: Attitudes of High School Seniors. Armed Forces \& Society, 13(2), 169-187. https://doi.org/10.1177/0095327X8701300201

Biro, M., Ajdukovic, D., Corkalo, D., Djipa, D., Milin, P., \& Weinstein, H. M. (2004). Attitudes toward justice and social reconstruction in Bosnia and Herzegovina and Croatia. In E. Stover \& H. M. Weinstein (Eds.), My Neighbor, My Enemy (pp. 183-205). Cambridge: Cambridge University Press. https://doi.org/10.1017/CBO9780511720352.013

Blattman, C. (2009). From Violence to Voting: War and Political Participation in Uganda. American Political Science Review, 103(2), 231-247. https://doi.org/10.1017/S0003055409090212

Bonanno, G. A., \& Jost, J. T. (2006). Conservative Shift Among High-Exposure Survivors of the September 11th Terrorist Attacks. Basic and Applied Social Psychology, 28(4), 311-323. https://doi.org/10.1207/s15324834basp2804_4

Brewin, C. R., Garnett, R., \& Andrews, B. (2011). Trauma, identity and mental health in UK military veterans. Psychological Medicine, 41(8), 1733-1740. https://doi.org/10.1017/S003329171000231X

Budge, I. (2001). Validating Party Policy Placements. British Journal of Political Science, 31(1), 179-223. https://doi.org/10.1017/S0007123401230087

Canetti, D., Elad-Strenger, J., Lavi, I., Guy, D., \& Bar-Tal, D. (2017). Exposure to Violence, Ethos of Conflict, and Support for Compromise: Surveys in Israel, East Jerusalem, West 
Bank, and Gaza. Journal of Conflict Resolution, 61(1), 84-113.

https://doi.org/10.1177/0022002715569771

Dahlberg, S., Linde, J., \& Holmberg, S. (2015). Democratic Discontent in Old and New

Democracies: Assessing the Importance of Democratic Input and Governmental Output. Political Studies, 63(1_suppl), 18-37. https://doi.org/10.1111/1467-9248.12170

Dekker, H., Malova, D., \& Hoogendoorn, S. (2003). Nationalism and Its Explanations. Political Psychology, 24(2), 345-376. https://doi.org/10.1111/0162-895X.00331

Diamond, L. J., \& Morlino, L. (2005). Assessing the quality of democracy. Baltimore: Johns Hopkins University Press.

Dyrstad, K. (2012). After ethnic civil war: Ethno-nationalism in the Western Balkans. Journal of Peace Research, 49(6), 817-831. https://doi.org/10.1177/0022343312439202

Feaver, P., \& Gelpi, C. (2005). Choosing your battles: American civil-military relations and the use of force ; with a new afterword by the authors (New ed.). Princeton, NJ: Princeton Univ. Press.

Fisher, S. (2006). Political change in post-Communist Slovakia and Croatia: from nationalist to Europeanist (1. ed). New York: Palgrave Macmillan.

Fontana, A., \& Rosenheck, R. (1998). Psychological benefits and liabilities of traumatic exposure in the war zone. Journal of Traumatic Stress, 11(3), 485-503. https://doi.org/10.1023/A:1024452612412

Getmansky, A., \& Zeitzoff, T. (2014). Terrorism and Voting: The Effect of Rocket Threat on Voting in Israeli Elections. American Political Science Review, 108(3), 588-604. https://doi.org/10.1017/S0003055414000288 
Glaurdić, J., \& Vuković, V. (2016). Voting after war: Legacy of conflict and the economy as determinants of electoral support in Croatia. Electoral Studies, 42, 135-145. https://doi.org/10.1016/j.electstud.2016.02.012

Grossman, G., Manekin, D., \& Miodownik, D. (2015). The Political Legacies of Combat: Attitudes Toward War and Peace Among Israeli Ex-Combatants. International Organization, 69(4), 981-1009. https://doi.org/10.1017/S002081831500020X

Hadzic, D., Carlson, D., \& Tavits, M. (2017). How Exposure to Violence Affects Ethnic Voting. British Journal of Political Science, 1-18. https://doi.org/10.1017/S0007123417000448

Harari, Y. N. (2005). Martial Illusions: War and Disillusionment in Twentieth-Century and Renaissance Military Memoirs. The Journal of Military History, 69(1), 43-72. https://doi.org/10.1353/jmh.2005.0023

He, Y. (2007). Remembering and Forgetting the War: Elite Mythmaking, Mass Reaction, and Sino-Japanese Relations, 1950-2006. History \& Memory, 19(2), 43-74.

Holman, E. A., \& Silver, R. C. (1998). Getting "stuck" in the past: Temporal orientation and coping with trauma. Journal of Personality and Social Psychology, 74(5), 1146-1163. https://doi.org/10.1037/0022-3514.74.5.1146

Irvine, J. A. (1997). Ultranationalist Ideology and State-Building in Croatia, 1990-1996. Problems of Post-Communism, 44(4), 30-43. https://doi.org/10.1080/10758216.1997.11655740

Jennings, M. K., \& Markus, G. B. (1977). The Effect of Military Service on Political Attitudes: A Panel Study. The American Political Science Review, 71(1), 131-147. https://doi.org/10.2307/1956958 
Kecmanovic, M. (2013). The Short-run Effects of the Croatian War on Education, Employment, and Earnings. Journal of Conflict Resolution, 57(6), 991-1010. https://doi.org/10.1177/0022002712454268

Kibris, A. (2011). Funerals and Elections: The Effects of Terrorism on Voting Behavior in Turkey. Journal of Conflict Resolution, 55(2), 220-247. https://doi.org/10.1177/0022002710383664

Klingler, J. D., \& Chatagnier, J. T. (2014). Are You Doing Your Part?: Veterans’ Political Attitudes and Heinlein's Conception of Citizenship. Armed Forces \& Society, 40(4), 673-695. https://doi.org/10.1177/0095327X12471932

Levine, L. J., Lench, H. C., \& Safer, M. A. (2009). Functions of remembering and misremembering emotion. Applied Cognitive Psychology, 23(8), 1059-1075. https://doi.org/10.1002/acp.1610

McBride, J., \& Simms, S. (2001). Death in the Family: Adapting a Family Systems Framework to the Grief Process. The American Journal of Family Therapy, 29(1), 59-73. https://doi.org/10.1080/01926180126032

Mudde, C. (2007). Populist radical right parties in Europe. Cambridge, UK; New York: Cambridge University Press.

Ostojic, M. (2009). Collective Memory In Personal Accounts Of Veterans Of The Croatian War 1991-1995. Socio-anthropologie, (23-24), 75-114. https://doi.org/10.4000/socioanthropologie. 1250

Outten, H. R., Schmitt, M. T., Garcia, D. M., \& Branscombe, N. R. (2009). Coping Options: Missing Links between Minority Group Identification and Psychological Well-Being. Applied Psychology, 58(1), 146-170. https://doi.org/10.1111/j.1464-0597.2008.00386.x 
Rabe-Hesketh, S., \& Skrondal, A. (2008). Multilevel and longitudinal modeling using stata (2nd ed). College Station, Tex: Stata Press Publication.

Ramet, S. P. (2006). The three Yugoslavias: state-building and legitimation, 1918-2005. Washington, D.C. : Bloomington, IN: Woodrow Wilson Center Press ; Indiana University Press.

Ringdal, K., \& Simkus, A. (2012). Appendix: Data and Methods. In K. Ringdal \& A. Simkus (Eds.), The Aftermath of War: Experiences and Social Attitudes in the Western Balkans (pp. 289-304). New York, NY: Routledge.

Simkus, A. (2007). Guest Editor's Introduction: The SEESSP Project. International Journal of Sociology, 37(3), 3-14. https://doi.org/10.2753/IJS0020-7659370300

Staub, E. (2006). Reconciliation after Genocide, Mass Killing, or Intractable Conflict: Understanding the Roots of Violence, Psychological Recovery, and Steps toward a General Theory. Political Psychology, 27(6), 867-894. https://doi.org/10.1111/j.14679221.2006.00541.x

Szayna, T. S. (Ed.). (2007). The civil-military gap in the United States: does it exist, why, and does it matter? Santa Monica, Calif.: Rand.

Tajfel, H., \& Turner, J. C. (1986). The social identity theory of intergroup behavior. In The social psychology of intergroup relations (pp. 7-24). Monterey, CA: Brooks/Cole.

Tanner, M. (1997). Croatia: a nation forged in war. New Haven [Conn.: Yale University Press. Retrieved from http://site.ebrary.com/id/10190707

Teigen, J. M. (2007). Veterans' Party Identification, Candidate Affect, and Vote Choice in the 2004 U.S. Presidential Election. Armed Forces \& Society, 33(3), 414-437. https://doi.org/10.1177/0002764206296586 
Wayment, H. A. (2004). It Could Have Been Me: Vicarious Victims and Disaster-Focused Distress. Personality and Social Psychology Bulletin, 30(4), 515-528. https://doi.org/10.1177/0146167203261892 
Notes:

1 Official press release of the the Croatian government (https://vlada.gov.hr/vijesti/u-registru489-407-hrvatskih-branitelja-od-kojih-157-037-dragovoljaca/6527)

2 The data used here are from the South East European Social Survey Project (SEESSP), Albert Simkus, director, funded by the Western Balkan program of the Research Council of Norway, grant no. $144826 / \mathrm{S} 30$.

3 This number takes into account missing values for the variables described below.

4 Croatian Bloc and Croatian True Revival entered the 2003 elections as a coalition.

5 An analysis of abstention showed that veterans were slightly less likely to abstain from voting than non-veterans. However, further investigation showed that the values of voters and abstainers did not differ. It is therefore unlikely that the results will be biased by the exclusion of abstaining voters.

6 Left-right self-placement scale is not used as this scale has been found to be poorly related to voters' policy positions (AUTHOR).

7 The full list of statements on which each preference dimension is based can be found in Tables A3-A5 in the appendix.

8 As a robustness check, we also calculated the factor scores of the preference dimensions, similar to the calculation of the war trauma variable. Though we found similar results, the models with factor scores for the preference dimensions had a substantially reduced sample of voters, by nearly $300(\mathrm{n}=667)$, and showed strong signs of type II error for some independent variables. Therefore, mean scores are used in the analyses below.

9 Croatia is divided into 21 counties, which are in turn further divided in 556 cities and municipalities. On average, a county has 26 cities or municipalities and 204,000 inhabitants. 